\section{TRND take two}

\section{By Chris Cain, Staff Writer}

With 14 projects in place, the NIH's Therapeutics for Rare and Neglected Diseases program has a full plate. Now, the program will shift focus from finding projects to building infrastructure and advancing compounds into the clinic.

In May 2009, NIH spent \$24 million to launch Therapeutics for Rare and Neglected Diseases (TRND), with the goal of advancing the preclinical development of compounds. ${ }^{1}$ Since its inception, TRND has started a total of 15 projects -5 pilot projects initially, followed by 4 projects in July $^{2}$ and 6 projects last month. Thus far, only one pilot project has been discontinued. Eight projects involve at least one biotech company.

Each of the 14 remaining projects targets a unique mechanism of action across 13 distinct rare or neglected disease areas (see Table 1, “TRND partnerships").

According to TRND director John McKew, the 14 projects represent "a full load with the current budget constraints" that TRND will maintain moving forward, using additional application rounds to replace completed projects or those that fail to meet program milestones. He expects to open a third round of applications next spring.

McKew, who also is chief of the Therapeutics Development Branch at the NIH Center for Translational Therapeutics, told SciBX the six projects started last month represent the end result of a year-long solicitation process in which TRND presented program details at roadshow meetings across the U.S. The applications TRND received were roughly split between academic teams and biotechs and were evaluated by a panel of about 25 scientists from academia and industry with experience in drug development.

"The application evaluation was something we specifically put together for TRND. It has mid- to high-level folks in pharma or biotech and venture capitalists who have day jobs evaluating projects and portfolios. We filled it in with academics who have successfully developed therapeutics in a former life or within an academic setting," said McKew.

After the review period, TRND took the top-scoring applications, signed confidentiality agreements and performed due diligence.

McKew said the process became more efficient over time. "Round one was the first time our reviewers got together-we gave them directions without knowing exactly how it would work. Since then, we have refined the application, provided more detailed guidance to the reviewers and learned how to more efficiently conduct due diligence."

For example, McKew said the program has become proficient at signing IP agreements. He said it can take as little as six to eight weeks for TRND and its partners to agree to a cooperative research and development agreement (CRADA) upon acceptance of a detailed project plan.

\section{Seeking rare success}

The second-round winners include a trio of biotechs. AVI BioPharma Inc. and Concert Pharmaceuticals Inc. are applying their antisense and deuteration technologies, respectively, to rare and neglected diseases. The third company, Lumos Pharma Inc., is seeking to treat creatine transporter deficiency (CTD) with a small molecule creatine mimetic.

AVI is conducting preclinical safety studies of a phosphorodiamidate morpholino oligomer, AVI-5038, that corrects splicing defects in exon 50 of the dystrophin gene to treat Duchenne muscular dystrophy (DMD). The company's lead product, Eteplirsen, which is in Phase II trials, uses the same technology to treat a distinct set of DMD patients with splicing defects in exon 51.

Concert is running preclinical studies of a deuterated form of praziquantel, a generic antischistosomiasis drug that requires repeated high dosing. The Concert compound has shown better stability in vitro than the parent molecule.

Lumos is developing a blood brain barrier-penetrant creatine mimetic to treat $\mathrm{X}$-linked CTD. The disease is caused by mutation of a creatine transporter, limiting the availability of creatine in the brain and leading to mental disability.

"Prevalence studies have pretty consistently pegged CTD as the number-two cause of X-linked mental disability, with about 8001,000 patients being born every year," said Joseph Clark, professor of neurology at the University of Cincinnati College of Medicine. "This is a profoundly debilitating disease."

There is no approved treatment for CTD.

Lumos spun out of the university based on Clark's work in animal models of CTD. The company's compound is a repurposed small molecule with an inactive IND for an undisclosed, acute indication. The TRND project seeks to complete IND-enabling chemistry, manufacturing and controls, and toxicology studies, which are necessary because use in CTD patients would be chronic.

\section{A growing TRND}

McKew says a focus for TRND over the next year will be to complete development of additional infrastructure to improve internal preclinical development capabilities.

"We are building 40,000 square feet of space, with support for medicinal chemistry, scaled-up small molecule production and 
Table 1. TRND partnerships. List of NIH Therapeutics for Rare and Neglected Diseases (TRND) partnerships as of Dec. $12,2011$. Source: NIH Center for Translational Therapeutics

\begin{tabular}{|c|c|c|c|}
\hline Company/institution & Compound & Target/mechanism & Indication \\
\hline \multicolumn{4}{|l|}{ Pilot projects } \\
\hline AesRx LLC & Aes-103 & $\begin{array}{l}\text { Small molecule that binds sickle } \\
\text { hemoglobin }\end{array}$ & Sickle cell disease \\
\hline $\begin{array}{l}\text { New Zealand Pharmaceuticals Ltd./National } \\
\text { Human Genome Research Institute }\end{array}$ & $\begin{array}{l}\text { N-Acetyl-D-mannosamine } \\
\text { (ManNAc) }\end{array}$ & Correct sialic acid deficiency & $\begin{array}{l}\text { Hereditary inclusion body } \\
\text { myopathy (hIBM) }\end{array}$ \\
\hline $\begin{array}{l}\text { Leukemia \& Lymphoma Society/The University of } \\
\text { Kansas Medical Center/National Heart, Lung, and } \\
\text { Blood Institute }\end{array}$ & Auranofin & $\begin{array}{l}\text { Selectively kills chronic } \\
\text { lymphocytic leukemia (CLL) cells }\end{array}$ & CLL \\
\hline $\begin{array}{l}\text { Niemann-Pick Type C disease foundations/ } \\
\text { Washington University in St. Louis/Albert } \\
\text { Einstein College of Medicine of Yeshiva University }\end{array}$ & $\begin{array}{l}\text { 2-Hydroxypropyl- } \beta \text {-cyclodextrin } \\
\text { (HPBCD) }\end{array}$ & $\begin{array}{l}\text { Reduction of cholesterol and } \\
\text { sphingolipid storage }\end{array}$ & $\begin{array}{l}\text { Niemann-Pick disease type C1 } \\
\text { (NPC1) }\end{array}$ \\
\hline \multicolumn{4}{|l|}{ First round of solicited projects } \\
\hline Afraxis Inc. & Not applicable & $\begin{array}{l}\text { p21 protein }(\mathrm{Cdc} 42 \mathrm{Rac})- \\
\text { activated kinase }(\mathrm{PAK}) \text { inhibitor }\end{array}$ & Fragile X syndrome \\
\hline ReveraGen Biopharma Inc. & VBP15 & $\begin{array}{l}\text { Modified glucocorticoid with } \\
\text { fewer side effects }\end{array}$ & $\begin{array}{l}\text { Duchenne muscular dystrophy } \\
\text { (DMD) }\end{array}$ \\
\hline Viamet Pharmaceuticals Inc. & VT-1129 & $\begin{array}{l}\text { Cytochrome P450 C-14 } \\
\alpha \text {-demethylase (CYP51) inhibitor }\end{array}$ & Cryptococcal meningitis \\
\hline National Human Genome Research Institute & Not applicable & $\begin{array}{l}\text { Inhibitor of core binding factor } \\
(\mathrm{CBF}) \text { protein interactions }\end{array}$ & $\begin{array}{l}\text { CBF-driven acute myelogenous } \\
\text { leukemia (AML) and acute } \\
\text { lymphoblastic leukemia (ALL) }\end{array}$ \\
\hline \multicolumn{4}{|l|}{ Second round of solicited projects } \\
\hline Harvard Medical School & $\begin{array}{l}\text { Dorsomorphin derivative (small } \\
\text { molecule) }\end{array}$ & $\begin{array}{l}\text { Bone morphogenetic protein type } \\
\text { I receptor inhibitor }\end{array}$ & $\begin{array}{l}\text { Fibrodysplasia ossificans } \\
\text { progressiva }\end{array}$ \\
\hline Lumos Pharma Inc. & $\begin{array}{l}\text { CincY, an undisclosed repurposed } \\
\text { molecule with an inactive IND }\end{array}$ & $\begin{array}{l}\text { Blood brain barrier-penetrant } \\
\text { creatine mimetic }\end{array}$ & $\begin{array}{l}\text { X-linked creatine transporter } \\
\text { defect (CTD) }\end{array}$ \\
\hline The University of Alabama at Birmingham & $\begin{array}{l}\text { CMX001, a lipophilic derivative of } \\
\text { cidofovir }\end{array}$ & $\begin{array}{l}\text { CNS-penetrant double-stranded } \\
\text { DNA viral synthesis inhibitor }\end{array}$ & $\begin{array}{l}\text { Neonatal herpes simplex virus } \\
\text { infection }\end{array}$ \\
\hline Concert Pharmaceuticals Inc. & $\begin{array}{l}\text { Deuterium-modified praziquantel } \\
\text { derivative }\end{array}$ & Small molecule antischistosome & Schistosomiasis \\
\hline AVI BioPharma Inc. & $\begin{array}{l}\text { AVI-5038, a phosphorodiamidate } \\
\text { morpholino oligomer targeting } \\
\text { dystrophin exon } 50\end{array}$ & $\begin{array}{l}\text { Corrects dystrophin exon } 50 \\
\text { splicing defect }\end{array}$ & $\begin{array}{l}\text { Duchenne muscular dystrophy } \\
\text { (DMD) }\end{array}$ \\
\hline Cincinnati Children's Hospital Medical Center & $\begin{array}{l}\text { Inhaled formulation of granulocyte } \\
\text { macrophage colony-stimulating } \\
\text { factor (GM-CSF; CSF2) }\end{array}$ & Restore GM-CSF function & Pulmonary alveolar proteinosis \\
\hline
\end{tabular}

analytic space to do additional pharmacology studies. We're also working to get an animal facility for pharmacokinetic studies."

TRND has a staff of 25-30 individuals and an annual budget of \$24 million. TRND plans to hire more people to work in the lab space as it comes online.

McKew emphasized that a key goal for TRND in 2012 is bringing additional compounds into clinical testing.

He noted that two INDs have now been filed for two small molecules from TRND projects-Aes-103 from AesRx LLC to treat sickle cell disease and Auranofin developed in collaboration with the Leukemia \& Lymphoma Society, The University of Kansas Medical Center and the National Heart, Lung, and Blood Institute for chronic lymphocytic leukemia (CLL). The first patient in the CLL project has been dosed in a Phase II trial at the University of Kansas Medical Center.

Aes-103 is a small molecule that increases the affinity of sickle cell hemoglobin for oxygen. Auranofin is a repurposed rheumatoid arthritis compound, marketed as Ridaura auranofin by Prometheus Laboratories Inc.
Cain, C. SciBX 4(48); doi:10.1038/scibx.2011.1341

Published online Dec. 15, 2011

\section{REFERENCES}

1. Usdin, S. SciBX 3(48); doi:10.1038/scibx.2010.1430

2. Cain, C. SciBX 3(40); doi:10.1038/scibx.2011.1105

\section{COMPANIES AND INSTITUTIONS MENTIONED}

AesRx LLC, Newton, Mass.

AVI BioPharma Inc. (NASDAQ:AVII), Bothell, Wash.

Concert Pharmaceuticals Inc., Lexington, Mass.

Leukemia \& Lymphoma Society, White Plains, N.Y.

Lumos Pharma Inc., Austin, Texas

National Institutes of Health, Bethesda, Md.

National Heart, Lung, and Blood Institute, Bethesda, Md.

NIH Center for Translational Therapeutics, Bethesda, Md.

Prometheus Laboratories Inc., San Diego, Calif.

University of Cincinnati College of Medicine,

Cincinnati, Ohio

The University of Kansas Medical Center,

Kansas City, Kansas 